thoracic surgery in lung cancer. Surg Today. 2009; 39:844-7.

4. Akiba T. Tailor-made virtual lung: prevailing clinical application. Gen Thorac Cardiovasc Surg. 2009;57:335-7

5. Akiba T, Marushima H, Makoto O, Harada J, Kobayashi S, Morikawa T. Pulmonary vein analysis using three dimensional computed tomography angiography for surgery. Gen Thorac Cardiovasc Surg. 2010;58:331-5.

doi:10.1016/j.jtcvs.2011.11.039

\section{GUIDING THE MOLECULAR DIAGNOSIS OF HYPERTROPHIC CARDIOMYOPATHY}

To the Editor:

With interest, we read the recent guideline for hypertrophic cardiomyopathy (HCM) and highly appreciate the useful clinical information. ${ }^{1}$ HCM is a pathophysiologically heterogeneous condition. We agree with the authors that there is comprehensive evidence that mutations in 8 genes encoding proteins of, or associated with, the sarcomere can cause HCM. These are, as stated in chapter 6 of the guideline, the genes encoding $\beta$ myosin heavy chain, myosin binding protein $\mathrm{C}$, troponin $\mathrm{T}$, troponin $\mathrm{I}$, $\alpha$-tropomyosin, actin, regulatory light chain, and essential light chain. However, only about $40 \%$ to $60 \%$ of HCM cases can be attributed to these 8 genes. $^{2,3}$

More recently, a ninth gene was convincingly linked to HCM after a genome-wide linkage analysis. $\mathrm{Mu}-$ tations in CSRP3 encoding muscle LIM protein were shown to cosegregate with HCM in several families in whom gene mutations in the 8 incriminated sarcomeric proteins had been previously excluded. ${ }^{4}$ All these mutations affected highly conserved residues and were not found in the control genomes. Linkage analysis with a highly significant 5.9 logarithm of the odds score in a single large family provided additional genetic evidence. Physicians and geneticists unaware of the mutation status ensured an unbiased attribution of disease status and an unbiased genome-wide linkage analysis in that family. ${ }^{5}$ Furthermore, functional data supported the genetic results. Cardiomyocyte disarray was observed in CSRP3 mutation-positive cardiac tissue from patients with HCM. The findings indicate that CSRP3 mutations cause "true" HCM and not merely a HCM phenocopy.

Although CSRP3 mutations in patients with HCM are not common $(<5 \%)$, we believe that there is convincing, scientific evidence that the gene should be included in the list of confirmed HCM disease genes. TPM1 and ACTC (encoding $\alpha$-tropomyosin and actin) mutations occur at a frequency not much different than CSRP3 mutations. The prevalence of HCM disease genes is also related to ethnicity. Such patterns require active surveillance of disease genes and CSRP3 should be included. To learn more about the ethnic spectrum of disease genes and specific founder mutations we propose including all well-established disease genes into scientific genetic screening analyses. Muscle LIM protein is not confined solely to sarcomeric localizations but can be localized to the sarcolemma and to the cell nucleus. Mechanistically, there is much to be learned about this protein, its gene, and their contributions to HCM. We therefore wish to draw attention to CSRP3.

Christian Geier, $M D^{a}$

Eric Schulze-Bahr, $M D^{b}$

Gisèle Bonne, $P h D^{c}$

${ }^{a}$ Experimental and Clinical Research

Center at the Max Delbrück Center

for Molecular Medicine

Charité Universitätsmedizin Berlin

Berlin, Germany

${ }^{b}$ Institut für Genetik von

Herzerkrankungen (IfGH)

Department für Kardiologie und Angiologie

Universitätsklinikum Münster

Münster, Germany

${ }^{c}$ Inserm

UMRS_974;
Université Pierre et Marie

Curie-Paris 6

UM 76

CNRS

UMR 7215

Institut de Myologie

IFR14;

AP-HP

Groupe Hospitalier Pitié-Salpêtrière U.F. Cardiogénétique et Myogénétique

Service de Biochimie Métabolique Paris, France

\section{References}

1. Gersh BJ, Maron BJ, Bonow RO, Dearani JA, Fifer MA, Link MS, et al. 2011 ACCF/AHA guideline for the diagnosis and treatment of hypertrophic cardiomyopathy: executive summary: a report of the American College of Cardiology Foundation/ American Heart Association Task Force on Practice Guidelines. J Thorac Cardiovasc Surg. 2011;142: 1303-38.

2. Richard P, Charron P, Carrier L, Ledeuil C, Cheav T, Pichereau C, et al. Hypertrophic cardiomyopathy: distribution of disease genes, spectrum of mutations, and implications for a molecular diagnosis strategy. Circulation. 2003;107:2227-32.

3. Van Driest SL, Vasile VC, Ommen SR, Will ML, Tajik AJ, Gersh BJ, et al. Myosin binding protein $\mathrm{C}$ mutations and compound heterozygosity in hypertrophic cardiomyopathy. J Am Coll Cardiol. 2004;44:1903-10.

4. Geier C, Perrot A, Özcelik C, Binner P, Counsell D, Hoffmann K, et al. Mutations in the human muscle LIM protein gene in families with hypertrophic cardiomyopathy. Circulation. 2003;107:1390-5.

5. Geier C, Gehmlich K, Ehler E, Hassfeld S, Perrot A, Hayess K, et al. Beyond the sarcomere: CSRP3 mutations cause hypertrophic cardiomyopathy. Hum Mol Genet. 2008;17:2753-65.

doi:10.1016/j.jtcvs.2012.01.062

\section{RE: SIMPLIFIED PERFUSION STRATEGY FOR REMOVING RETROPERITONEAL TUMORS WITH EXTENSIVE CAVOATRIAL INVOLVEMENT}

\section{To the Editor:}

The authors compare beating heart cardiopulmonary bypass (CPB) and hypothermic circulatory arrest (HCA) for removing retroperitoneal tumors with extensive cavoatrial involvement. ${ }^{1}$ They included in their series retroperitoneal renal tumors with level III-IV tumor thrombus 
extension; $56(39 \%)$ and $88(61 \%)$ underwent $\mathrm{CPB}$ and $\mathrm{HCA}$, respectively. Since 1997, we have used liver transplant techniques for mobilization of the liver off the inferior vena cava (piggyback mobilization) to aid in the resection of renal cell carcinoma with level III tumor thrombus. ${ }^{2}$ None of the patients required a thoracoabdominal approach, CBP, HCA or venovenous bypass. Just recently, we published our technique step by step for treating renal cell carcinoma with tumor thrombus, extending our experience to 56 patients with level III and 12 with level IV tumor thrombus, and only 3 patients with level IV required $\mathrm{CPB} .^{3}$ This experience has now been extended to 70 patients with level III thrombus. We also reported our experience removing an adherent ${ }^{4}$ and nonadherent ${ }^{5}$ level IV (intra-atrial thrombus) tumor thrombus without a thoracoabdominal approach, median sternotomy, or $\mathrm{CPB}$. It is important to describe other experiences of treating renal cell carcinoma with level III-IV cavoatrial involvement in which CPB or HCA can be avoided for most cases, thereby simplifying the operation even more.

Javier González, $M D^{a}$
Thomas Salerno, MD
Gaetano Ciancio, MD
Gervicio de Urologia Hospital
Universitario de Getafe
Seriversidad Europea de Madrid
Getafe, Madrid, Spain
Union
${ }^{b}$ Division of Cardiothoracic Surgery
${ }^{c}$ Department of Surgery (Division of
Transplantation) and Urology
University of Miami Miller School of
Medicine
Jackson Memorial Hospital
Miami, Fla

\section{References}

1. Navia JL, Brozzi NA, Nowicki ER, Blackstone EH, Krishnamurthi V, Sinkewich MG, et al. Simplified perfusion strategy for removing retroperitoneal tumors with extensive cavoatrial involvement. J Thorac Cardiovasc Surg. July 22, 2011 [Epub ahead of print].

2. Ciancio G, Vaidya A, Savoie M, Soloway M. Management of renal cell carcinoma with level III thrombus in the inferior vena cava. J Urol. 2002; 168:1374-7.

3. Ciancio G, González J, Shirodkar SP, Angulo JC, Soloway MS. Liver transplantation techniques for the surgical management of renal cell carcinoma with tumor thrombus in the inferior vena cava: step-by-step description. Eur Urol. 2011;59: 401-6.

4. Cerwicka WH, Ciancio G, Salerno TA, Soloway M. Renal cell cancer with invasive atrial tumor thrombus excised off-pump. Urology. 2005;66:1318, e9-11.

5. Ciancio G, Soloway M. Renal cell carcinoma with tumor thrombus extending above the diaphragm: avoiding cardiopulmonary bypass. Urology. 2005; 66:266-70.

doi:10.1016/j.jtcvs.2011.11.040

\section{Notices of Correction}

Re: Akins CW. The ethical dilemma of Thoracic Surgery recertification. J Thorac Cardiovasc Surg. 2012;143:521-2.

In the above-mentioned article, the abbreviation for Maintenance of Certification was incorrect throughout. The correct abbreviation is MOC.

Re: Hillis LD, Smith PK, Anderson JL, Bittl JA, Bridges CR, Byrne JG, Cigarroa JE, DiSesa VJ, Hiratzka LF, Hutter AM Jr, Jessen ME, Keeley EC, Lahey SJ, Lange RA, London MJ, Mack MJ, Patel MR, Puskas JD, Sabik JF, Selnes O, Shahian DM, Trost JC,Winniford MD. 2011 ACCF/AHA guideline for coronary artery bypass graft surgery: Executive summary: A report of the American College of Cardiology Foundation/American Heart Association Task Force on Practice Guidelines. J Thorac Cardiovasc Surg. 2012;143:4-34.

In Section 4.10.3, Central Nervous System Monitoring, in Class IIb recommendation \#1, references 449-51 should be replaced by the following references, which should be added to the References section:

316a. Avidan MS, Zhang L, Burnside BA, et al. Anesthesia awareness and the bispectral index. $N$ Engl J Med. 2008;358:1097-108.

316b. Hemmerling TM, Olivier JF, Basile F, et al. Bispectral index as an indicator of cerebral hypoperfusion during off-pump coronary artery bypass grafting. Anesth Analg. 2005;100:354-6.

316c. Myles PS, Leslie K, McNeil J, et al. Bispectral index monitoring to prevent awareness during anaesthesia: the B-Aware randomised controlled trial. Lancet. 2004;363:1757-63.

References 449-451 should be deleted from the References section. These changes are for concordance with the full-length guideline article (J Am Coll Cardiol. 2011;58:e123-210; doi:10.1016/j.jacc.2011.08.009). 